\title{
An Investigation of the Relationship Between University Prep Class Students' Intelligence Types and Their Success of Foreign Language Learning
}

\author{
İsmail, Y., Gülünay ${ }^{1} \&$ Seyfi, Savaş2,* \\ ${ }^{1}$ Institute of Education Sciences, Gazi University, Ankara, Turkey \\ ${ }^{2}$ Faculty of Sport Sciences, Gazi University, Ankara, Turkey \\ *Correspondence: Faculty of Sport Sciences, Gazi University, Ankara, Turkey. E-mail: seyfi@gazi.edu.tr
}

Received: June 21, 2019

Accepted: July 22, 2019 Online Published: August 25, 2019

doi:10.5430/wje.v9n4p97

URL: https://doi.org/10.5430/wje.v9n4p97

\begin{abstract}
In the 21 st century, when foreign language learning has become almost compulsory, everyone is trying to fulfill this obligation. In fact, foreign language has become a very important thing not only for the people who work on linguistic sciences but also for politicians, academicians, and even sportsmen. In this context, the main purpose is to compare the English achievement levels of students with physical/kinesthetic intelligence to those with other intelligence areas. 198 males, 66 females, in total 267 students, who study at Karabuk University, School of Foreign Languages during the summer term of 2017-2018, have participated in this study. "Personal Information Form" developed by researchers; "Multiple Intelligence Observation Form" from the book "Multiple Intelligence Applications" (2003) by Selçuk, Kayılı, Okut; Karabük University Preparatory Summer School foreign language success averages for determining the English achievement levels of the students, have been used as data collection tools. Kolmogorov Smirnov, Mann-Whitney U, Kruskal Wallis, and Spearman Correlation tests have been used to analyze the data. Consequently, there are no significant differences between the foreign language scores of the students according to the variables of doing sports with a license, gender, age, and licensed sports branches. However, there is a significant difference between the foreign language scores of the students according to the variable of exercising regularly $(\mathrm{p}=0.04<0.05)$. There is no statistically significant relationship between students' multiple intelligences and foreign language scores.
\end{abstract}

Keywords: multiple intelligence, physical activity, exercise, foreign language

\section{Introduction}

One of the most important needs for the growth, progression, and development of a society's welfare level is the communication that individuals of that society have established with each other. Communication is achieved through language, and competence in this area is important for every field. It can be said that knowing at least one foreign language is very important to keep up with the continuously changing and globalizing world. According to Özdemir (2006), it is important for individuals to learn, know and use international common language to be able to communicate and maintain them in all kinds of areas. When both technological and economic developments are considered, it is seen that the language which collects many societies in common is "English". As Koru and Akesson (2011) mentioned, knowing English is not a privilege in Turkey too, it is also a need. According to İşcan (2011), learning foreign languages offers many opportunities such as communicating with people from different nations, academic success, awareness and understanding of different cultures, developing tolerance with different cultures, expressing oneself, taking part in the global world.

However, language learning may not be an easy task for everyone. Some people spend their days, weeks or even years, while others are able to make progress in a much shorter period of time. It is known that lots of expressions, such as "You tend to learn languages.", "I cannot learn like you whatever I do, I have difficulties in understanding" are directed at these kinds of people. According to Gardner (1987), there are eight different types of intelligence (verbal, logical, visual, musical, physical, nature, interpersonal, intrapersonal) and at least one of them is known to be more dominant than the others. It can be said that the dominant intelligence of an individual, who is more 
successful in foreign language learning, is verbal intelligence. However, this does not mean that it is a prerequisite for success in foreign language learning. Armstrong (2009) suggests that the classroom environment must be tailored to address everyone, thereby the rate of success will increase. Instead of being just a traditional teacher who lectures only writing on the board, teachers can give lecture by drawing pictures on the board, showing videos related to the subject, making students listen to music on a certain part of the day, giving practical training and asking students to produce something that proves they have learned something. Every intelligence has its own developmental path, and the small factors that can be experienced in these paths can have great effects, every intelligence type can reach a peak or a decline that can be quick or gradual (Gardner, 1987). For example, a person skilled in linguistics can play an instrument very well or perform sports successfully at the same time. In this case, it means that s/he is dominant in more than one intelligence. According to Armstrong (2009), one should avoid saying "strong intelligence" or "weak intelligence" when describing the difference between an individual's intelligences, because if appropriate opportunities are provided for the intelligence called "weak", it may become the strongest side of a person.

More passive lives, which come up with technology, is perhaps one of the biggest problems of the day. There is no doubt about the contribution of physical education lessons carried out at schools or voluntary physical activities. According to Bailey (2006), physical activity and physical education bring great service by addressing all the developmental processes (cognitive, affective, psychomotor). It can be said that being interested in physical education lessons or being volunteer about the activities which is run by body are preferred by individuals with physical intelligence from Gardner's Multiple Intelligence Theory.

When we think about the relationship between foreign language learning and physical activity, the contribution they make to each other, arouse curiosity. When studies (Castelli et al., 2007; Carlson et al., 2008; Blom et al., 2011; Bezold et al., 2014) are examined, dealing with physical activities has a positive effect on the development of language skills. In addition, Ericsson (2008), Haapala (2012) and Esteban-Cornejo et al. (2015) have concluded that physical activity increases general academic achievement. The purpose of this study is to determine the multiple intelligences of the university students in the foreign language preparatory class, whether they exercise or not; and to reveal the difference between them and foreign language learning success.

\section{Method}

\subsection{Measures}

"Personal Information Form" developed by researchers; "Multiple Intelligence Observation Form" from the book "Multiple Intelligence Applications" by Selçuk, Kayıll, Okut (2003); Karabuk University Preparatory Summer School foreign language success means for determining the English achievement levels of the students, were used as data collection tools. Multiple Intelligence Observation Form's Cronbach Alpha value is 0.92. With the help of SPSS package program, analysis of the data was made, the demographic characteristics of the students were revealed, Kolmogorov Smirnov values of the data were examined and Mann Whitney U, Kruskal Wallis, and Spearman Correlation tests were used.

\subsection{Participants}

The students, who studied at Karabuk University, School of Foreign Languages during the 2017-2018 academic year, formed the population of the study and in total 264 students, who studied at summer school in the same academic year, formed the sample.

\section{Results}

According to Table 1, $198(75.0 \%)$ of the total participant number of 264 students, are males, and $66(25.0 \%)$ of it are females. $229(86.8 \%)$ of the students who participated in the study are between the ages of 17-19 and $35(13.2 \%)$ are between the ages of 20-22. While $161(61.0 \%)$ of the total students exercise regularly, $103(39.0 \%)$ do not. 29 $(11.0 \%)$ students are engaged in a sports branch while $235(89.0 \%)$ students are not. $12(41.37 \%)$ of the students, who are engaged in a sports branch, play football, 7 (24.13\%) of them play basketball, $5(17.25 \%)$ of them play volleyball and the last $5(17.25 \%)$ play other sports. 
Table 1. Demographic Information about the Participants

\begin{tabular}{|c|c|c|c|}
\hline Variable & & $\mathrm{f}$ & $\%$ \\
\hline \multirow[t]{3}{*}{ Gender } & Male & 198 & 75.0 \\
\hline & Female & 66 & 25.0 \\
\hline & Total & 264 & 100.0 \\
\hline \multirow[t]{3}{*}{ Age groups } & $17-19$ & 229 & 86.8 \\
\hline & $20-22$ & 35 & 13.2 \\
\hline & Total & 264 & 100.0 \\
\hline \multirow[t]{3}{*}{ Exercising regularly } & Yes & 161 & 61.0 \\
\hline & No & 103 & 39.0 \\
\hline & Total & 264 & 100.0 \\
\hline \multirow[t]{3}{*}{ Doing sport with a license } & Yes & 29 & 11.0 \\
\hline & No & 235 & 89.0 \\
\hline & Total & 264 & 100.0 \\
\hline \multirow[t]{5}{*}{ Sports branches } & Football & 12 & 41.37 \\
\hline & Basketball & 7 & 24.13 \\
\hline & Volleyball & 5 & 17.25 \\
\hline & Others & 5 & 17.25 \\
\hline & Total & 29 & 100.0 \\
\hline
\end{tabular}

Table 2. Multiple Intelligences and Foreign Language Achievement Mean of Participants

\begin{tabular}{lcccccccc}
\hline Variable & Verbal & Logical & Visual & Musical & Physical & Nature & Interpersonal & Intrapersonal \\
\hline Male & 0 & 63 & 16 & 10 & 47 & 37 & 14 & 11 \\
Female & 2 & 14 & 7 & 6 & 7 & 17 & 8 & 5 \\
Total & 2 & 77 & 23 & 16 & 54 & 54 & 22 & 16 \\
Intelligence means & 38 & 34 & 34 & 35 & 35 & 36 & 34 & 34 \\
Foreign language & 48 & 71 & 72 & 71 & 70 & 69 & 71 & 73 \\
achievement means & & & & & & & & \\
\hline
\end{tabular}

As seen in the table 2, $77(29.16 \%)$ participants have logical intelligence, $54(20.45 \%)$ participants have physical intelligence, $54(20.45 \%)$ participants have nature intelligence, $23(8.71 \%)$ participants have visual intelligence, 22 $(8.33 \%)$ participants have interpersonal intelligence, $16(6.06 \%)$ participants have intrapersonal intelligence, 16 (6.06\%) participants have musical intelligence, and $2(0.75 \%)$ participants have verbal intelligence. When the means of dominant intelligence are examined, it is seen that the highest mean of all is the verbal and physical intelligence is the third intelligence. When the mean of foreign language achievement is examined according to dominant intelligence, it is found that the mean of intrapersonal is 73 , visual is 72 , interpersonal, musical and logical are 71 , physical is 70 , nature is 69 and verbal is 48 .

Table 3. Mann Whitney u Test According to the Variable of Gender

\begin{tabular}{llccccc}
\hline & Gender & $\mathrm{n}$ & Mean rank & Sum of ranks & Mann whitney u & $\mathrm{p}$ \\
\hline \multirow{2}{*}{ Foreign language score } & Male & 198 & 130.51 & 25841.00 & \multirow{2}{*}{6140.00} & \multirow{2}{*}{0.46} \\
& Female & 66 & 138.47 & 9139.00 & & \\
\hline
\end{tabular}

As seen in table 3, there are not any statistically meaningful differences between foreign language scores according to gender variable $(\mathrm{p}=0.46>0.05)$.

Table 4. Mann Whitney u Test According to the Variable of Exercising Regularly

\begin{tabular}{llccccc}
\hline & Exercising regularly & $\mathrm{n}$ & Mean rank & Sum of ranks & Mann whitney u & $\mathrm{p}$ \\
\hline Foreign & Yes & 161 & 140.05 & 22548.00 & & \\
language & No & 103 & 120.70 & 12432.00 & & $\mathbf{0 . 0 4}$ \\
score & No & & & & & \\
\hline
\end{tabular}


It is determined that there is a statistically meaningful difference between foreign language scores according to exercising regularly variable $(\mathrm{p}=0.04<0.05)$ in table 4 .

Table 5. Mann Whitney u Test According to the Variable of Doing Sports with a License

\begin{tabular}{llccccc}
\hline & $\begin{array}{l}\text { Doing sports } \\
\text { with a license }\end{array}$ & $\mathrm{n}$ & Mean rank & Sum of ranks & Mann whitney u & $\mathrm{p}$ \\
\hline Foreign & Yes & 29 & 121.62 & 3527.00 & 3092.00 & 0.41 \\
language score & No & 235 & 133.84 & 31453.00 & 300 \\
\hline
\end{tabular}

According to table 5, there are no statistically meaningful differences between foreign language scores according to the variable of doing sports with a license $(\mathrm{p}=0.41>0.05)$.

Table 6. Kruskal Wallis h Test According to the Variable of Licensed Sports Branch

\begin{tabular}{llccccc}
\hline & Sports branch & $\mathrm{n}$ & Mean rank & $\mathrm{df}$ & $\mathrm{x}^{2}$ & $\mathrm{p}$ \\
\hline \multirow{3}{*}{ Foreign language } & Football & 12 & 145.08 & & & \\
score & Basketball & 7 & 110.71 & 4 & 4.10 & 0.39 \\
& Volleyball & 5 & 72.20 & 4 & & \\
& Other & 5 & 130.00 & & & \\
\hline
\end{tabular}

There are not any statistically meaningful differences between foreign language scores according to the variable of licensed sports branch of students in table $6(\mathrm{p}=0.39>0.05)$.

Table 7. Mann Whitney u Test According to Variable of Age

\begin{tabular}{llccccc}
\hline & Age group & $\mathrm{n}$ & Mean rank & $\begin{array}{c}\text { Sum of } \\
\text { ranks }\end{array}$ & Mann whitney u & $\mathrm{p}$ \\
\hline Foreign & $17-19$ & 229 & 131.01 & 30002.00 & 3667.00 & 0.41 \\
language score & $20-22$ & 35 & 142.23 & 4978.00 & 0.400 \\
\hline
\end{tabular}

It is seen in table 7 that there are no meaningful differences between foreign language scores according to participants' ages $(\mathrm{p}=0.41>0.05)$.

Table 8. The Relationship between Foreign Language Scores and Multiple Intelligences

\begin{tabular}{|c|c|c|c|c|c|c|c|c|c|}
\hline & & Verbal & Logical & Visual & Musical & Physical & Interpersonal & Intrapersonal & Nature \\
\hline $\begin{array}{l}\text { Foreign } \\
\text { language }\end{array}$ & $\begin{array}{l}\text { Spearman } \\
\text { correlation } \\
\text { coefficient }\end{array}$ & 0.033 & 0.084 & 0.011 & 0.037 & -0.036 & 0.043 & 0.064 & -0.088 \\
\hline score & $\mathrm{p}$ & 0.589 & 0.172 & $\begin{array}{r}0.856 \\
264\end{array}$ & $\begin{array}{c}0.548 \\
264\end{array}$ & 0.562 & 0.483 & 0.302 & 0.152 \\
\hline
\end{tabular}

According to table 8 , there are no meaningful differences between foreign language scores and multiple intelligences of students.

\section{Discussion and Conclusion}

As seen in table 3, there aren't found any differences between foreign language scores according to the gender of students. Kobayashi (2002) found that girls had a higher attitude than boys in learning English; Blom et al. (2011) found that girl primary and secondary school students were more successful in language skills than boys; Rosnayawati \& Kaswan (2017) concluded that gender didn't have any effect on reading skills of students. It can be said about the differences between these conclusions that they can result from their study samples.

According to table 4, there is a meaningful difference between foreign language scores according to the variable of exercising regularly. Blom et al. (2011) found that students who dealt with physical activities were more successful than those who did not exercise regularly in language skills; Castelli et al. (2007) resulted that physically fit students were more successful in reading than those who were not fit; Carlson et al. (2007) found in their study, which they 
studied with primary school students, that girls who got more physical education classes in terms of hours were more successful than others both in general and in reading skills. When Käll, Nilsson, and Lindé (2014)'s study in Sweden has been examined, in addition to the regular physical education courses, additional physical activity programs twice a weekly schedule were administered by the professionals for 4 years, and it was observed that the students in the experimental group were more successful in the English course than the students in the control group. Käll et al. (2014) also said that expanded physical activity increased student concentration and thus academic achievement could increase. Schmidt-Kassow et al. (2010), provided vocabulary teaching to one group while they were doing physical activity, and to another group, while they were passive, in their study with 12 volunteers, aged between 19 and 33, in Germany. According to the results of the study, the group which was active during the learning process gained higher learning rates than the other group. Bezold et al. (2014), studied with 83.111 secondary school students and tried to find out the relationship between physical fitness and academic performance. They used standardized English and maths tests for the study and as a result; those who increased their fitness level had higher scores in these tests. In this context, the results of these studies are similar to this study. When the student profile is considered, if the students are at the compulsory education level, they can be given more effective physical education courses during the school period; if they are at the university levels, they can be encouraged for regular exercise.

There are not any meaningful differences between foreign language scores according to the students doing sports with a license variable ( $\mathrm{p}=0.41>0.05)$ in table 5 . According to table 6 ; there is no meaningful difference between foreign language scores according to licensed sports branches $(\mathrm{p}=0.39>0.05)$. However, Daley and Ryan (2000) found a weak negative correlation between English scores and the time spent on physical activities in their studies that they studied with 13-16 aged children. Fox et al. (2010) studied with secondary and high school students in 2010 and reported that participating in sports teams and doing physical activities affected general academic achievement positively. The reason for not matching results may be because of personal differences.

As it is seen in table 7, there are no meaningful differences between foreign language scores according to students' ages $(\mathrm{p}=0.41>0.05)$. Nikolov and Djigunović (2006) stated in their study that being exposed to foreign language at an early age was the key to solve all the problems and for a good learning. Also, Dong and Ren (2013) stated that learning a foreign language was a more complex thing with adults and the age was very important. Munoz (2010) stated that learning the target language at an earlier age might be important, provided that they were exposed to that language adequately and significantly and the target language was used in the social context. But the ages of students are very close in this study, and they are not in the quality of being compared to each other, so this may be shown as the reason why meaningful differences cannot be seen.

There aren't any meaningful differences between foreign language scores and any of multiple intelligences according to table 8. Arnold and Fonseca (2004) stated that the classroom should be equipped with various activities that engage different intelligences to provide students deep learning thus the lesson could appeal to all students from all intelligences and students could gather attention better. Armstrong (2009), emphasized that the classroom environment should be changed from the traditional form and decorated with activities, so students could be active, and it could appeal to all. According to the result of the study, classes should be organized in the forms of having more different activities that draw more attention from more student.

In conclusion there are no meaningful differences between foreign language scores according to any variables except for "exercising regularly" $(\mathrm{p}=0.04<0.05)$. When the results of this study have been taken into consideration, these suggestions are revealed for further studies;

It is important to enlarge the population of study to get more effective and accurate results; during foreign language education, physical activity programs, which support it, should be organized and students should be encouraged to join them.

\section{References}

Armstrong, T. (2009). Multiple intelligences in the classroom. Virginia: Ascd, 2009.

Arnold, J., \& Fonseca, M. C. (2004). Multiple intelligence theory and foreign language learning: A brain-based perspective. International journal of English studies, 4(1), 119-136.

Bailey, R. (2006). Physical education and sport in schools: A review of benefits and outcomes. Journal of school health, 76(8), 397-401. https://doi.org/10.1111/j.1746-1561.2006.00132.x

Bezold, C. P., Konty, K. J., Day, S. E., Berger, M., Harr, L., Larkin, M., ... \& Stark, J. H. (2014). The effects of changes in physical fitness on academic performance among New York City youth. Journal of Adolescent 
Health, 55(6), 774-781. https://doi.org/10.1016/j.jadohealth.2014.06.006

Blom, L. C., Alvarez, J., Zhang, L., \& Kolbo, J. (2011). Associations between health-related physical fitness, academic achievement and selected academic behaviors of elementary and middle school students in the state of Mississppi. The ICHPER-SD Journal of Research in Health, Physical Education, Recreation, Sport \& Dance, 6(1), 13.

Carlson, S. A., Fulton, J. E., Lee, S. M., Maynard, L. M., Brown, D. R., Kohl III, H. W., \& Dietz, W. H. (2008). Physical education and academic achievement in elementary school: data from the early childhood longitudinal study. American journal of public health, 98(4), 721-727. https://doi.org/10.2105/AJPH.2007.117176

Castelli, D. M., Hillman, C. H., Buck, S. M., \& Erwin, H. E. (2007). Physical fitness and academic achievement in third-and fifth-grade students. Journal of Sport and Exercise Psychology, 29(2), 239-252. https://doi.org/10.1123/jsep.29.2.239

Daley, A. J., \& Ryan, J. (2000). Academic performance and participation in physical activity by secondary school adolescents. Perceptual and motor skills, 91(2), 531-534. https://doi.org/10.2466/pms.2000.91.2.531

Dong, G., \& Ren, H. (2013). The role of age in second language acquisition-a psychological perspective. British Journal of English Linguistics, 1(1), 1-6.

Ericsson, I. (2008). Motor skills, attention and academic achievements. An intervention study in school years 1-3. British Educational Research Journal, 34(3), 301-313. https://doi.org/10.1080/01411920701609299

Esteban-Cornejo, I., Tejero-Gonzalez, C. M., Sallis, J. F., \& Veiga, O. L. (2015). Physical activity and cognition in adolescents: A systematic review. Journal of Science and Medicine in Sport, 18(5), 534-539. https://doi.org/10.1016/j.jsams.2014.07.007

Fox, C. K., Barr-Anderson, D., Neumark-Sztainer, D., \& Wall, M. (2010). Physical activity and sports team participation: Associations with academic outcomes in middle school and high school students. Journal of school health, 80(1), 31-37. https://doi.org/10.1111/j.1746-1561.2009.00454.x

Gardner, H. (1987). The theory of multiple intelligences. Annals of Dyslexia, 37(1), 19-35.

Haapala, E. (2012). Physical activity, academic performance and cognition in children and adolescents. A systematic review. Baltic Journal of health and physical activity, 4(1), 53.

Işcan, A. (2011). Türkçenin yabancı dil olarak önemi. International Journal Of Eurasia Social Sciences, 4.

Käll, L. B., Nilsson, M., \& Lindén, T. (2014). The impact of a physical activity intervention program on academic achievement in a Swedish elementary school setting. Journal of school health, 84(8), 473-480. https://doi.org/10.1111/josh.12179

Kobayashi, Y. (2002). The role of gender in foreign language learning attitudes: Japanese female students' attitudes towards English learning. Gender and education, 14(2), 181-197. https://doi.org/10.1080/09540250220133021

Koru, S., \& Akesson, J. (2011). Türkiye'nin İngilizce açı̆̆̆. Ankara: Türkiye Ekonomi Politikaları Araştırma Vakfı.

Muñoz, C. (2010). On how age affects foreign language learning. Advances in research on language acquisition and teaching, 39-49.

Nikolov, M., \& Djigunović, J. M. (2006). Recent research on age, second language acquisition, and early foreign language learning. Annual review of applied linguistics, 26, 234-260. https://doi.org/10.1017/S0267190506000122

Özdemir, E. A. (2006). Türkiye'de İngilizce öğreniminin yaygınlaşmasının nedenleri. Mersin Üniversitesi Eğitim Fakültesi Dergisi, 2(1).

Rosnayawati, W., \& Kaswan, K. (2017). The influence of gender and language learning strategy preferences towards students'reading comprehension. Eltin Journal, Journal of English Language Teaching in Indonesia, 4(1).

Selçuk, Z., Kayıl1, H., \& Okut, L. (2003). Çoklu zekâ uygulamaları. Ankara: Nobel.

Schmidt-Kassow, M., Kulka, A., Gunter, T. C., Rothermich, K., \& Kotz, S. A. (2010). Exercising during learning improves vocabulary acquisition: behavioral and ERP evidence. Neuroscience letters, 482(1), 40-44. https://doi.org/10.1016/j.neulet.2010.06.089 